\title{
СОЦІАЛЬНІ ПРОБЛЕМИ НАУКОВИХ ДОСЛІДЖЕНЬ
}

\section{Л. Г. Трусей, Л. М. Трусей}

Стаття присвячена проблемі міждисциплінарних досліджень соціальної направленості в такий тяжкий для всього людства період, як перехід від епохи варварства до епохи иивілізації. Відсутні фундаментальні наукові прачі загального характеру які б були фаховим інструментом в соиіальній практиці. Окремі міждисциплінарні дисципліни не в змозі відповісти на всі питання сьогодення. Очевидно, на наш погляд, щзо деякий набір міждисциплінарних дисциплін системно об'єднаних на принципах міжсистемних взаємодій сформує, достатній з точки зору повноти, інструментарій вивчення та прогнозування соціальних явищ. Актуальність теми підкреслюється тим, щзо складність соціальних процесів на далі буде збільщуватись.

Ключові слова: сочіальна практика, міждисциплінарність, ноосфера, онтологія, системні методи, методологія, інваріантне моделювання.

The article is sanctified to the problem of interdisciplinary researches of social orientation in such heavy for all humanity period, as transition from the epoch of barbarism to the epoch of civilization. Fundamental scientific works of general character are absent, what would be a professional instrument in social practice. Separate interdisciplinary disciplines are unable to answer all questions of present time. Obviously, in our view, that some set of interdisciplinary disciplines of the intersystem co-operations system incorporated on principles will form, sufficient from the point of view of plenitude, tool of study and prognostication of the social phenomena. Actuality of theme is underlined by that complication of social processes will increase farther.

Keywords: social practice, interdisciplinary researches, no sphere, ontology, system methods, methodology, invariant design.

Статья посвящена проблеме междисииплинарных исследований сочиальной направленности в такой тяжельй для всего человечества период, как переход от эпохи варварства к эпохе иивилизации. Отсутствуют фундаментальные научные труды общего характера, какие бы были профессиональным инструментом в социальной практике. Отдельные междисииплинарные дисииплины не в состоянии ответить на все вопросы нынешнего времени. Очевидно, на наш взгляд, что некоторый набор междисииплинарных дисииплин системно объединенных на принципах межсистемных взаимодействий сформирует, достаточный с точки зрения полноты, инструментарий изучения 
и прогнозирования социальных явлений. Актуальность темы подчеркивается тем, что сложность социальных прочессов дальще будет увеличиваться.

Ключевые слова: сочиальная практика, междисииплинарные исследования, ноосфера, онтология, системные методы, методология, инвариантное моделирование.

Постановка проблеми. Роль наукових досліджень соціальних явищ в суспільстві важко переоцінити. Ці дослідження повинні стати основними на етапі переходу людства в епоху цивілізації [1]. Інтерес до таких досліджень визначається передусім масштабом і практичною необхідністю. Особлива роль відводиться міждисциплінарним дослідженням, які по суті об’єднують знання, методи, засоби і передові навички учених-фахівців різних напрямів у вивченні загального для них об’єкту - соціальних явищ. Міждисциплінарні дослідження найважливіша відмінна риса і характерна особливість сучасної науки і також вимога соціальної практики [2]. Тільки до кінця XX століття стало ясно, що вузькоспеціальні науки, вузький дисциплінарний підхід не дозволяє ні вивчати, ні зрозуміти усі соціальні процеси, що ускладнюються. В. І. Вернадський говорив про зростаючу складність і масштабність великих проблем в житті людства і розвитку наукового знання [3]. Їх не можна вирішити силами окремих наук, наскільки б узагальненими вони не були. Дослідження реальних соціальних систем по окремим частинам окремими науками не дає адекватного їх розуміння і пояснення. Саме міждисциплінарний підхід дає можливість утілити вимогу часу про цілісне вивчення явища, його елементів, взаємодій елементів, а також і на рівні міжсистемних взаємодій $[4,5]$.

Аналіз останніх досліджень і публікацій. Методологічну основу даної роботи склали відповідні праці: Вернадського В. І., Бабича В. П., Малюти О. М., Панарина О. С., Задорожного Г. В., та інших. Враховуючи, що зростання складності реальних теоретичних і практичних завдань набагато перевищує по своїй швидкості зростання особистих можливостей окремо взятої людини, то проблема створення додаткових можливостей підтримки людини нині виникає в усіх життєво важливих сферах діяльності. Особливо гостро ця проблема стоїть в розумовій діяльності. Вона зажадала зміни стереотипу мислення і створення нових, загальніших підходів до розуміння дійсності. Окрім складності завдань, що стоять перед людством, існуюча базова сукупність глобаль- 
них ідей, пов'язаних з розумінням світу людиною і свого місця в нім неминуче повинно кардинально змінитися. Такі зміни потребують появу нових глобальних універсальних філософських концепцій і напрямів, що відповідають по рівню своєї загальності, мірі розробленості, проблематиці моделювання, можливостям формалізації і широті предметної області духу часу. Окремі дослідження не об'єднані загальним вектором практичної направленості наукових розробок. Тому стоїть нагальна потреба введення в концептуально-понятійне середовище гуманітарних дисциплін таких міждисциплінарних теорій, які спроможні ефективно формувати нові стереотипи мислення, характерних для людини третього тисячоліття и як наслідок цього, процесу світорозуміння і системної організації своєї безпосередньої діяльності.

Якщо виділити приклади досліджень в цьому напрямі нині, то обмежимося розглядом і загальною характеристикою трьох абсолютно нових наукових дисциплін - це загальна методологія (методологія більш високого філософського рівня), прикладна онтологія і системні методи третього покоління. Названі напрямки наукових досліджень в теперішній час уже заявили про себе. Але про них знає дуже вузький прошарок спеціалістів. На наш погляд, задача полягає в тому, щоб ці знання стали надбанням широкого загалу, зокрема для спеціалістів які займаються соціальною практикою та управлінською діяльністю, а також що ці наукові дисципліни стануть інструментом розуміння і опису складних соціальних процесів сучасних і майбутніх суспільств, що обумовлює їх подальший розвиток.

Причини появи загальної методології полягають в наступному: жодна $з$ приватних наукових дисциплін не може представити її в готовому виді, здатною до застосування іншими; відсутні єдина наукова мова, термінологія, система критеріїв; фактично немає наукових праць за загальною методологією; відсутній системний підхід в осмисленні загальної методології; немає таких загальнонаукових засобів як моделювання, яке по суті є ядром інтеграції наукових знань; не залучені до загальної методології такі нові поняття і концепції, як синергетика, ноосфера, онтологія, екологія, значення людини, тобто як повернути в систему суб'єкт діяльності (людський чинник); немає підходу до аналізу і вирішенню складних глобальних проблем. Загальна методологія включає як метод прикладну онтологію і системні методи третього покоління. 
Причини появи прикладної онтології полягають в наступному [1]: скороченням гуманітарних дисциплін в системах середньої і вищої освіти; ускладненням соціальних процесів і не здатністю сучасної науки їх адекватно пояснити; переходом людства в штучну епоху - епоху цивілізації, яка зажадала наукового обгрунтування закономірностей земного буття людини; розширенням відповідальності людини за свої дії до глобального рівня. Фактично прикладна онтологія - це філософія, спущена з далеких висот до практичного застосування людиною в сучасному житті з усуненням абстрактних узагальнень і властивих філософії істотних обмежень як загальної науки.

Причини появи системних методів третього покоління (теорія гіперкомплексних динамічних систем або інше найменування дисципліни - інваріантне моделювання) [6] полягають в наступному: відсутністю нових світоглядного рівня теорій; відсутністю нових (застарілі не годяться) технологій соціального будівництва; вузькоспеціальна підготовка в системі освіти; відсутністю наукових методів дослідження аномальних явищ; відсутність наукового інструментарію охоплення розумінням загального і можливостей синтезу; немає наукової основи підготовки полі функціональних фахівців, особливо у сфері управління; немає науки, яка вивчає діяльність як таку; відсутністю досить повного набору фундаментальних принципів і закономірностей, що відносяться саме до систем і тим самим що виділяють їх як специфічний об'єкт і предмет дослідження; велика кількість підходів і методів об'єднаних поняттям система зумовило необхідність створення наукового напряму, предметом якого стали власне системи, їх основні закономірності і властивості; не вирішено завдання адекватності наукового тлумачення соціальних процесів; відсутністю взаємодії природознавчих, гуманітарних і технічних наук, об'єднаних єдиною метою; відсутністю досліджень по вивченню так званого комплексного підходу (насправді системні методи третього покоління включають і поняття комплексного підходу); відсутністю інструментарію вивчення глобальних проблем. Помилково вважається, що системний, комплексний і глобальний підходи представляють різні рівні междисциплинарности, що відображають зростаючу складність соціальних проблем, які стоять перед людством. Насправді системні методи третього покоління включають усі підходи і тому $є$ універсальними. 
Виклад основного матеріалу. На основі вищесказаного, завдання дослідження полягає в загальній характеристиці запропонованих трьох міждисциплінарних дисциплін, окреслення областей їх застосування, а також можливостей їх взаємодій та подальшого розвитку.

Загальна методологія. Загальна методологія покликана виробити єдиний загальнометодологічний підхід, який синтезував би результати різних напрямів методологічних досліджень. Філософія, як основа методології, грає велику роль в міждисциплінарних дослідженнях, тому подальший розвиток самої філософіï, подолання певних обмежень іiі категорій дозволить зміцнити іiі зв'язок з іншими окремими науками в методологічному сенсі. Загальна методологія покликана стати головним інструментом рішення в першу чергу глобальних проблем, які стоять на першому плані діяльності людини і ставлять перед нею дуже серйозні виклики. Загальна методологія покликана розв'язати проблему методологічної неповноти і несумісності методологій окремих дисциплін. На нашу думку, загальна методологія може стати об'єднуючим фактором методологій інших дисциплін як універсальний інструмент практичної діяльності людини. Приведемо визначення загальної методології. Загальна методологія - це система принципів та способів (методів) теоретичної та практичної діяльності людини та людства в цілому. Кожне слово в цьому визначенні має дуже важливе значення. Слово система означає, що принципи і способи об'єднані системними взаємодіями, сформовані в структуру, мають цілісність 3 новою якістю, якої не мали елементи системи. Крім того, ієрархічний рівень загальної методологи стає найвищим. Тобто, рівень системної організації загальної методології повинен бути не нижче п'ятого рівня. Подальші вивчення та розробки теорії загальної методології повинно врахувати вищесказане і підняти iï на самий високий рівень міждисциплінарних теорій.

Прикладна онтологія [1]. Нова галузь науково-прикладних знань про суть, сенс і цілі земного буття людини і його розумну взаємодію 3 навколишньою природою. Ця галузь світової науки покликана визначити основні етапи еволюційного розвитку інтелектуальних і духовних здібностей людини, дати об'єктивну цілісну картину сучасного світу з усіма іiі позитивними і негативними явищами і тенденціями, усебічно обгрунтувати найбільш вірогідні перспективи подальшого впорядкування життєдіяльності людей на земній планеті. Прикладна 
онтологія покликана «з'єднати що раніше не з'єднувалося», а значить сформувати двоєдину загальнолюдську, достовірну наукову концепцію духовно-матеріалістичного пізнання світу. Дух і матерія розглядаються не як протиборчі першооснови, а постійно взаємодіючі, взаємодоповнюючі і взаємозбагачувальні складові земного життя і діяльності кожного індивіда-землянина і усіх мешканців нашої загальної планети. Прикладна онтологія відкриває реальні можливості пізнання первинних витоків неповноцінності і порочності багатоликих систем індивідуального, кланово-групового і суспільно-політичного світогляду, що стихійно сформувалися. 3 іншого боку, прикладна онтологія є науковим потенціалом спрямованим на формування універсальної загальної земної системи цивілізованої, збалансованої побудови матеріального і духовного буття людини в умовах загального ненасильницького світу.

Сьогодні роль прикладної онтології про перегляд картини світу і місця в нім людини стоїть як ніколи гостро і повинна грунтуватися на новому антропологічному принципі - миследіяльності. Діяльність людини в XXI столітті - це головне завдання як науки, так і кожної людини як земного мешканця.

Об’єднувальну функцію консолідації і координації безлічі наукових розробок і досліджень сучасних проблем глобалізації світу повинна виконати прикладна онтологія, як особлива галузь наукових знань про основні закони еволюції і найбільш раціональний уклад життя і діяльності людей на земній планеті. У минулому така галузь науки не могла виникнути в силу природної обмеженості людського інтелекту і повсюдного панування різноманітних і несумісних національних, релігійних і кланово-групових інтересів, традицій і переваг [4].

Сучасна історія ультимативно спонукає усіх землян розширити горизонти бачення світу до загально-земних проблем існування суспільства і навколишньої природи. Настав час для кожної сучасної цивілізованої людини міцно усвідомити, що від успішного рішення цих глобальних проблем безпосередньо залежить історична доля людства і кожного землянина в XXI столітті і третьому тисячолітті нашої ери. Якщо попереднє століття називають століттям науково-технічного прогресу і кардинального поліпшення матеріальних умов земного буття, то XXI століття повинне привнести до історії людства не менш 
значимі досягнення в області науково-інтелектуального прогресу та еволюційних перетворень духовного життя усіх прийдешніх поколінь людей.

Створення науково-теоретичних основ прикладної онтології в найближчій перспективі дозволить залучити усіх людей до знань, специфіки об'єктивних загальнолюдських законів і вимог, а в той же час дозволить привести їх суб'єктивні, часто егоїстичні, інтереси і пристрасті в належну відповідність загально-земним нормам розумного, цивілізованого мислення і поведінки на нашій загальній планеті.

Системні методи третього покоління [6]. Ці методи розроблені на усіх можливих рівнях представлення наукових теорій : вербальному, символьному (формалізованому), алгоритмічному, 3 можливістю ЕВМ реалізації, ігровому. Це знання завтрашнього дня. Це новий міждисциплінарний підхід, що дозволяє будувати системні моделі і проводити міждисциплінарний аналіз складних об'єктів, процесів і явищ незалежно від їх фізичної природи. Служить фундаментом для побудови ідеології, що претендує на роль нової світоглядної основи людини третього тисячоліття. Може застосовуватися на стиках науки, релігії, культури, аномальних явищ і езотеричних знань. Має здатність ефективно формувати нові стереотипи мислення, характерного для людини третього тисячоліття, у якого активізується процес світобачення і системної організації своєї безпосередньої діяльності. Основні положення системних методів третього покоління є корисними, а іноді і обов'язковими для управлінців різного рівня, яким необхідно швидко орієнтуватися і приймати відповідальні рішення в складних ситуаціях нашого часу.

Існують і інші приклади міждисциплінарних досліджень, нас же більшою мірою цікавлять наведені вище.

Висновки. Застосування в соціальній практиці приведених міждисциплінарних теорій стане основою кардинальної зміни системи світобачення і відповідної переорієнтації освіти і виховання нових поколінь людей на формування високої культури повноцінного наукового мислення і цивілізованого співіснування на нашій планеті.

Нескоро-минуща цінність такого методологічного підходу полягає в тому, що він дозволяє також виявити істинні першоджерела і першо- 
причини величезної безлічі дрібномасштабних діянь і вчинків людей, значна частина яких $є$ порочною і злочинною внаслідок традиційної обмеженості, суб'єктивізму і егоїзму людського мислення.

Оцінка рівня ефективності засвоєння цих теорій може виступати спеціальним тестом по відбору людей, придатних до управлінської діяльності, які покликані приймати стратегічно важливі рішення.

Немає сумніву в тому, що світова суспільно-гуманітарна наука, до якої поза сумнівом відносяться приведені в статті міждисциплінарні теорії, має достатній потенціал знань для практичного здійснення таких грандіозних історичних перетворень і здійснити історичну місію загального переходу до ненасильницького, цивілізованого світу.

\section{Література}

1. Бабич В. П., Могилко В. А., Онєгіна В. М. Прикладна онтологія.- Харків.: Мадрид, 2013.

2. Фромм Э. Здорове суспільство, - М.: АСТ, 2009.

3. Вернадський В. І. Наукова думка як планетне явище. Під ред. Яншина А. Л.—- М.: Наука, 1991.

4. Бабич В. П. і др. Проблеми і перспективи науково-онтологічних знань. Препринт наукової доповіді Харківського інституту управління. — Харків, 2011.

5. Задорожный Г. В., Задорожная О. Г. Людина господарююча: онтологічні підстави цілісної добрісної життєдіяльності в глобальному кризовому світі. - Препринт доповіді на міському міждисциплінарному семінарі. Харків, 2016.

6. Малюта А. Н. Гіперкомплексні динамічні системи. - Львів.: Выща школа при Львівському держ. університеті, 1989. 